\title{
USPOREDBA SPOZNAJNOG I EMOCIONALNOG ASPEKTA SLUŠANJA GLAZBE U GLAZBENO-PEDAGOŠKOM KONTEKSTU OSNOVNE ŠKOLE
}

\author{
Sabina Vidulin ${ }^{1}$, Marlena Plavšićc ${ }^{2}$, Valnea Žauhar ${ }^{3}$ \\ ${ }^{1}$ Muzička akademija u Puli, Sveučilište Jurja Dobrile u Puli, \\ Hrvatska, svidulin@unipu.hr \\ ${ }^{2}$ Filozofski fakultet, Sveučilište Jurja Dobrile u Puli, \\ Hrvatska,mplavsic@unipu.hr \\ ${ }^{3}$ Filozofski fakultet, Sveučilište u Rijeci, \\ Hrvatska, vzauhar@ffri.hr
}

Primljeno: 16. 6. 2019.

Cilj je slušanja glazbe u školi oblikovati kulturno-umjetnički svjetonazor učenica $i$ učenika te doprinijeti njihovom estetskom odgoju. U hrvatskim osnovnim školama realizira se prema tzv. standardnom modelu kojemu je težište na spoznajnoj dimenziji. Kako bi se povećali pozornost, motivacija, slušalačke navike i prihvaćanje umjetničke glazbe, predlaže se spoznajno-emocionalni pristup koji višemodalno povezuje glazbene i izvanglazbene sadržaje. Cilj istraživanja bio je usporediti utjecaje spoznajno-emocionalnog $i$ standardnog pristupa u nastavi glazbene kulture na spoznajni i emocionalni aspekt slušanja glazbe. Sudjelovalo je 557 učenika i učenica iz 30 petih razreda. Slušali su Hačaturjanovu Maskaradu, Beethovenovu Wellingtonovu pobjedu, Rimski-Korsakovljevu Šeherezadu i Fauréovu Pavanu te odgovarali na pitanja vezana za spoznajni i emocionalni aspekt slušanja glazbe. Petnaest razreda imalo je nastavu po standardnom, a 15 razreda po spoznajno-emocionalnom pristupu. U spoznajnom aspektu odgovori učenika i učenica uglavnom se nisu razlikovali. $U$ emocionalnom aspektu, $u$ Šeherezadi $i$ Pavani nešto su intenzivnije doživljavane dominantne emocije kada je bio primijenjen spoznajno-emocionalni pristup.

Ključne riječi: slušanje glazbe, glazbena djela, nastava glazbene kulture, standardni pristup, spoznajno-emocionalni pristup 


\section{Uvod}

\section{Spoznajna paradigma u slušanju glazbe}

Područje slušanja glazbe svoje je mjesto u nastavnim programima hrvatskih škola dobilo tek nakon Drugog svjetskog rata, od 1948., kada se koncepcija predmeta Pjevanje i aktivnost pjevanja koja je bila i ostala još desetljećima dominantna, proširila i na slušanje glazbe. Slušanje glazbe otada je prisutno u nastavi glazbe kao jedno od područja, da bi 2006. preuzelo dominaciju i postalo jedinim obveznim područjem. Razvidno je da se nakon rata nije moglo govoriti o kvaliteti obrazovanja, fono-uređajima niti o učiteljima/učiteljicama koji su reprezentativno mogli izvoditi glazbenu nastavu, no vidljiv je interes za to područje.

Premda je slušanje glazbe ovisilo o mogućnostima škole, vještini učitelja/učiteljica za prezentiranjem djela sviranjem ili pjevanjem, njihovom znanju o glazbenoj literaturi, kao i korištenju tadašnje tehnike, Duraković (2016) ističe da su se slušale ploče, a uvedeno je i slušanje radijskih emisija jer se smatralo da će na taj način učenice i učenici bolje upoznati glazbenu literaturu. Već tada slušanje glazbe nije se sagledavalo kao izdvojeno područje, nego je spajano s područjem nazvanim Glazbeni život, a danas je poznato pod nazivom Upoznavanje glazbene literature. Prateći cilj i zadaće slušanja i upoznavanja glazbe kroz nastavne programe od poslijeratnih godina do današnjeg dana, vidljiva je orijentacija prvenstveno ka spoznajnoj dimenziji nastave.

Slušanje i upoznavanje glazbenih djela služe tome da se odgoji i obrazuje kompetentan slušatelj/slušateljica i poznavatelj/poznavateljica glazbe. U zadnjim dekadama 20. stoljeća ustoličio se standardni (konvencionalni) pristup slušanju glazbe koji je postao dijelom prakse uslijed metodičkih pristupa koje su nudili Požgaj (1988), a nakon njega Rojko (1996). Iako je Požgaj slušanje glazbe sagledavao i kroz neku vrstu emocionalnoga konteksta, ali bez konkretne razrade i veće izloženosti, Rojkov pristup naglašava usmjerenost prema glazbenom djelu, odnosno glazbenim sastavnicama koje se uočavaju tijekom slušanja glazbe s vrlo preciznim pitanjima kojima se potiče pozornost učenika i učenica. Na toj paradigmi obrazovano je mnogo generacija glazbenih pedagoginja i pedagoga. Koncepcija slušanja bila je i još uvijek jest orijentirana na sljedeće etape: postavljanje pitanja kojima se učenici i učenice motiviraju na aktivno praćenje glazbenog djela, slušanje glazbe i razgovor. Pitanja se postavljaju prije slušanja glazbenog djela, a nakon 
slušanja učenici i učenice razgovaraju s učiteljicama i učiteljima o prvobitno postavljenim pitanjima.

Aktivno slušanje glazbenog djela, ali isto tako prema prvenstveno spoznajnom principu pronalazi se i u Nastavnom planu i programu (2006). Takav pristup podrazumijeva opažanje glazbeno-izražajnih sastavnica, glazbenih vrsta i oblikovnih struktura glazbenog djela. Najčešće se polazi od utvrđivanja naziva skladbe i imena skladatelja, tempa, dinamike, ugođaja i karaktera, izvođača (instrumenti, glasovi, sastavi), glazbenog oblika, glazbene vrste do melodijskih i ritamskih specifičnosti i sl., a redoslijed njihova uvođenja ovisi o nastavnom programu za svaki pojedini razred. Sličan, ali i proširen način poimanja slušanja glazbe pronalazi se i kod Spasojević-Stojanović (2013). Autorica ističe da slušanje može biti globalno (u cjelini, bez analize i opažanja, s naglaskom na emocionalni kontekst), selektivno (podrazumijeva misaonu aktivnost učenica i učenika na osnovu zadanih zadataka) te globalno slušanje više razine (obuhvaća dodavanje različitih oblika glazbenog izražavanja i stvaranja) (prema: Stojanović, 1996). S druge strane, pitanjima emocija u glazbi kao primarnog zadatka glazbenog djela bave se skladatelji/skladateljice na različite načine: u djelima imitiraju govor, usuglašavaju razine riječi s harmonijama, sve u cilju da glazba dotakne i proizvede emociju (Perlovsky, 2010).

Ako se razmišlja o djelovanju glazbe na učenike i učenice, važno je utvrditi na koji način doživljaj i prihvaćanje glazbe koja nije odraz njihovih preferencija djeluje na njih. Isto tako, emocionalno uživljavanje u/kroz glazbu postavlja pred učiteljice i učitelje izazov kako metodički postaviti nastavnu jedinicu.

\section{Emocionalni aspekt slušanja glazbe}

Posljednjih tridesetak godina intenzivirala su se istraživanja o povezanosti glazbe i emocija (Cespedes-Guevara i Eerola, 2018; Corrigall i Shellenberg, 2013). Rezultati pokazuju da glazba slušatelju/slušateljici prenosi, ali i pobuđuje emocije, uključujući osnovne (npr. sreću, tugu) i složenije emocije koje se odnose na estetiku (npr. divljenje, čuđenje, nostalgiju; Juslin et al., 2008). Emocionalne reakcije uslijed slušanja glazbe razlikuju se kod različitih slušatelja i slušateljica (Juslin i Laukka, 2004; Juslin et al., 2008), a emocije se tijekom slušanja mogu, ali i ne moraju manifestirati. 
Brojne se glazbene sastavnice sustavno pokazuju povezanima s emocionalnim reagiranjem. Na primjer, brži tempo povezuje se uz veselje i ljutnju, dok je spori tempo povezan s tugom i nježnosti. Glasnoća, boja i artikulacija mogu biti povezane s visokom ili niskom razinom uzbuđenja, dok su akustička obilježja koja se vezuju uz valenciju emocija (ugodno, neugodno) temeljena na pravilnostima u intenzitetu, frekvenciji i trajanju (Juslin i Laukka, 2003). Također, istraživanja uobičajeno pokazuju povezanost durskih tonaliteta s ugodnim emocijama, a molskih s neugodnim (Gabrielsson i Juslin, 2003). Iznimno jake emocionalne reakcije za vrijeme slušanja glazbe (ganutost, plakanje, trnci) često se podudaraju sa specifičnim obilježjima glazbenih djela poput melodijskih appoggiatura ili neočekivanih harmonijskih progresija (Sloboda, 1991).

Izloženost glazbi i iskustvo slušanja glazbe u svakodnevnim situacijama oblikuje sposobnost djece da percipiraju i doživljavaju emocije. Kod djece se najčešće ispituje sposobnost identifikacije emocija izraženih glazbom poput sreće i tuge. Odrastanjem i izlaganjem glazbi djeca istovremeno postaju sve osjetljivija i na emocionalne konotacije specifične za pojedinu kulturu pa primjerice durske tonalitete povezuju sa srećom, a molske s tugom (Dalla Bella et al., 2001). Drugi znakovi koji predviđaju identifikaciju emocija su ritmičnost, metar i artikulacija, pa će djeca bogatu ritmičnost glazbe povezivati sa srećom i uzbuđenjem, dvodobne mjere sa smirenošću, trodobne s uzbuđenjem, staccato sa srećom, a legato s tugom (Kratus, 1993). Oko jedanaeste godine života djeca dostižu izvedbu odraslih u zadacima diskriminacije emocija u glazbi (Hunter, Schellenberg i Stalinski, 2011).

U novije vrijeme Juslin i suradnici (Juslin, 2013; Juslin i Västfjäll, 2008; Juslin et al., 2010), polazeći od evolucijske perspektive, objašnjavaju mehanizme uključene u emocionalni doživljaj glazbe. Mehanizmi koje navode obuhvaćaju refleks moždanog debla, evaluacijsko uvjetovanje, usklađivanje s ritmom, emocionalnu zarazu, vizualnu imaginaciju, epizodičko pamćenje, očekivanje o tijeku glazbe te estetsku procjenu. Koji će se mehanizam aktivirati prilikom slušanja glazbe i hoće li se aktivirati, ovisi o karakteristikama glazbenog djela (npr. izražajnost, neočekivani harmonijski tijek, dinamičke promjene, tempo), karakteristikama konteksta u kojem se glazba sluša (npr. usmjereno slušanje, slušanje pozadinske glazbe, estetsko oblikovanje, vrsta situacije u kojoj se glazba sluša) i karakteristikama slušatelja/slušateljice (npr. 
glazbene preferencije, osobine ličnosti, trenutačno stanje organizma, prethodno znanje; Juslin, 2013). Ipak, od svih navedenih mehanizama, tri se mehanizma najčešće aktiviraju tijekom svakodnevnog života (Juslin et al., 2008; Juslin et al., 2011). Prvi je refleks moždanog debla, odnosno mehanizam koji odgovara na jednostavna akustička obilježja poput ekstremne glasnoće ili brzine, te pojačavanja i ubrzavanja (Sokolov, 1963). Drugi je mehanizam emocionalne zaraze koji se aktivira kad se emocija izražena kroz glazbu internalizira, što osobito može biti potaknuto glavnom melodijom koju izvodi glas ili instrument sličnih karakteristika poput violončela (Juslin, 2000). Treći je mehanizam epizodičkog pamćenja koji podrazumijeva svjesni doziv određenog događaja iz slušateljičine/slušateljeve prošlosti koji je potaknut glazbom (Baumgartner, 1992), a smatra se da emocije pobuđene ovim mehanizmom odražavaju emocionalni ton evociranog sjećanja (Juslin, Barradas i Eerola, 2015).

Osim navedenoga, emocionalna reakcija ovisit će i o slušateljevu/ slušateljičinu usmjeravanju pažnje, o vrsti glazbe koja se sluša (Eerola, 2011) te o svim drugim potencijalno relevantnim informacijama u okolini. Važnu ulogu u emocionalnoj reakciji čini i značenje koje se glazbi pridaje (Juslin, Barradas i Eerola, 2015), a ono može proizlaziti iz interakcije različitih glazbenih karakteristika, znanja i ciljeva osobe koja sluša, karakteristika situacije u kojoj se glazba sluša i mogućnostima izražavanja ponašanja u toj situaciji (Cespedes-Guevara i Eerola, 2018; Clarke, 2005; DeNora, 2003; Russel, 2003).

Iako istraživanja pokazuju da glazba može evocirati emocionalnu reakciju, potrebno je napomenuti da se emocije u glazbi prije i češće percipiraju nego što se doživljavaju. Pri tome, emocionalna reakcija češće se manifestira nakon percepcije emocija. Također, percipirane i doživljene emocije najčešće jesu povezane, no nisu identične, a iako su slušatelji i slušateljice u pravilu sposobni identificirati emociju koju glazba prenosi, istu emociju ne moraju i doživjeti. S druge strane, emocije koje se mogu javiti tijekom slušanja glazbe ne moraju odgovarati emocionalnoj izražajnosti glazbe (Hunter, Shellenberg i Shimack, 2010).

\section{Spoznajno-emocionalni pristup slušanju glazbe}

Imajući u vidu relevantne čimbenike koji sudjeluju u stvaranju sveobuhvatnog glazbenog doživljaja, Vidulin i Radica (2017) osmislile 
su spoznajno-emocionalni pristup koji je inspiriran promjenom težišta slušanja glazbe u školi. Namjera je utjecati na kulturno-umjetnički svjetonazor učenica i učenika, obnavljati repertoar slušanja u školi, ponuditi pristup koji na dubljoj razini spaja spoznajnu i emocionalnu dimenziju te pridonosi prihvaćanju glazbenog djela na osobnoj razini.

Budući da se taj pristup može sagledati iz različitih perspektiva, naša je namjera ukazati na njegov glazbeno-pedagoški kontekst. U takvom se kontekstu glazbena djela sagledavaju ne samo kroz prepoznavanje glazbenih sastavnica i teorijskih obilježja djela nego kao puno šira tvorevina, kao dokument koji svjedoči o vremenu i kontekstu nastajanja, društvenim, vjerskim i političkim prilikama, ideologiji, stajalištima, vjerovanjima, kako na osobnoj razini (skladatelj/skladateljica) tako i profesionalnoj (glazbeno-stilsko razdoblje pripadanja). Polazi od pretpostavke da će skladba biti trajnije usvojena ako je učenici i učenice dožive i prožive, percipiraju njezine sastavnice, upoznaju se sa životom i radom skladatelja/skladateljice, smjeste djelo u kontekst vremena i društvenih okolnosti i sl. Na taj način proces kojim se želi utjecati na to da učenice i učenici prihvate glazbu može se ubrzati, osobito ako se pritom potakne i emocionalno uživljavanje.

Vidulin i Plavšić (2020) se, u studiji kojom istražuju spoznajnoemocionalni pristup slušanju glazbe, vode upoznavanjem djela i skladatelja kroz pomno osmišljen proces razgovora i diskusije, demonstracijom dijelova skladbe ili cjeline sa specifičnim zadacima, ponovnim razgovorom s elementima zaključka. Glazba se doživljava pjevanjem/ sviranjem melodije, izvođenjem ritamskog obrasca, izvođenjem glazbenog oblika plesom i sl. Zadaci analitičkog karaktera koji vode prema glazbenom znanju (oblici, vrste, izvođači/izvođačice i sl.) obogaćuju se zadacima asocijativnog karaktera, emocionalnog konteksta i prelaze granice isključivo glazbenog okružja. Motivacijska aktivnost prije slušanja ili uz slušanje glazbe ima za svrhu povećati pozornost i koncentraciju učenica i učenika na djelo koje se obrađuje, potaknuti njihov interes, omogućiti aktivno sudjelovanje i muziciranje učenika i učenica, kako bi se bolje pridonijelo pamćenju djela i povećala vjerojatnost prihvaćanja djela na osobnoj razini.

Slušati glazbu prema spoznajno-emocionalnom pristupu treba naučiti najprije učitelj/učiteljica, imajući u vidu i da, kako Milanković ističe (2018), uz emocionalni učinak glazbe na čovjeka, važnu ulogu ima i estetski kao i etički učinak. U zajedništvu emocionalnih i estet- 
skih iskustava, ideala, impulsa, nadahnuća, ali i etičke odgovornosti, slušatelj/slušateljica može procijeniti kvalitetu glazbe. Vješti glazbenik, metodičar i glazbenica, metodičarka, nakon pomnog istraživanja i proučavanja djela, višestrukog slušanja i određivanja teorijskog, muzikološkog, estetskog i etičkog konteksta djela, osobitu će pozornost obratiti na motiviranje učenica i učenika, aktivno uključivanje u nastavni proces te pronalaženje načina emocionalnog prijama skladbe, sve u svrhu prihvaćanja glazbenog djela.

\section{Cilj i hipoteze}

Cilj ovog istraživanja bio je ispitati utjecaj spoznajno-emocionalnog i standardnog pristupa slušanja glazbe u nastavi glazbene kulture na spoznajni i emocionalni aspekt slušanja glazbe. Iz navedenog cilja proizlaze dvije hipoteze:

H1: S obzirom na to da su i standardni i spoznajno-emocionalni pristup usmjereni na spoznajni aspekt slušanja glazbe, pretpostavljeno je da u spoznajnom aspektu slušanja glazbe neće biti razlika ovisno o pristupu slušanju glazbe.

H2: S obzirom na to da spoznajno-emocionalni pristup u većoj mjeri nego standardni uključuje elemente poticanja na emocionalno doživljavanje glazbe, pretpostavljeno je da će učenici i učenice koji su sudjelovali u nastavi po spoznajno-emocionalnom pristupu snažnije doživjeti emocije u odnosu na one koji su glazbu slušali po standardnom pristupu.

\section{Metodologija}

\section{Sudionice i sudionici}

U istraživanju je sudjelovalo 557 učenika i učenica iz 30 petih razreda. Bilo je uključeno 16 osnovnih škola iz 12 hrvatskih gradova iz različitih županija. Podjednako je bilo učenika (49 \%) i učenica (51 \%), a u prosjeku su imali 10.6 godina $(\mathrm{SD}=0.54)$. Istraživanje je provedeno u prvom polugodištu šk. god. 2018/2019.

\section{Odabir glazbenih djela}

Za potrebe istraživanja odabrana su četiri instrumentalna umjetnička djela koja inače nisu uključena u program nastave glazbene kulture: 
Maskarada, Valcer Arama Hačaturjana, Wellingtonova pobjeda Ludwiga van Beethovena, Šeherezada, More i Sindbadov brod Nikolaja Rimski-Korsakova i Pavana Gabriela Fauréa. Program za slušanje glazbe u osnovnoj školi, prema Nastavnom planu i programu (2006), orijentiran je uglavnom ilustracijski i prati fenomene koji se obrađuju tijekom godina školovanja. Potreban iskorak od već uvriježenih djela poželjan je i potreban kako bi se učenice i učenici upoznali i s nekim drugim djelima i skladateljima/skladateljicama.

Četiri glazbena djela odabrana su na temelju različitih glazbenih, ali i pedagoških kriterija. Glede pedagoških, važno je bilo pronaći glazbeno djelo kraćega trajanja (najbolje do 5 minuta), kako bi se ono moglo više puta slušati tijekom jednoga nastavnoga sata ili djelo dužeg trajanja koje se može raščlaniti na manje dijelove koji čine cjelinu. Isto tako, važno je bilo postaviti djelo u širi kontekst kako bi se i izvanglazbenim elementima moglo doprinijeti prihvaćanju glazbenoga djela. Glede glazbenih karakteristika, u pojedinim djelima odabir je bio uvjetovan ritamskim i/ili melodijskim specifičnostima koje su prvenstveno sluhom zamjetljive (a ne slikom partiture), zatim strukturalnim specifičnostima u kojima prednjače motivi, fraze te dvodijelni i trodijelni glazbeni oblici, ponavljanje, variranje, potom karakternim osobinama djela, odnosno jasno razlučivim glazbenim sastavnicama i parametrima (od tempa i dinamike do ugođaja i tonskoga roda). Pri odabiru djela vodilo se računa i o tome da glazbene karakteristike tih djela mogu prenijeti i/ili potaknuti različite emocionalne doživljaje. Iz navedenog razloga odabrana su djela različitih tempa (npr. sporiji tempo povezan je s tugom, ali i sa sjetom i nježnošću, a brži s uzbuđenjem, veseljem ili ljutnjom), ugođaja (npr. mirnija djela mogu biti povezana s tugom, ali i spokojem i opuštenošću, a dinamična djela s uzbuđenjem, uznemirenošću i ljutnjom), razina tonskih i dinamičkih varijacija (npr. izražene varijacije u dinamici i visini tonova mogu biti povezane sa strahom i s uznemirenošću, a ujednačenija dinamika i manji tonski raspon u durskim tonalitetima mogu biti povezani s veseljem; Dobrota i Reić Ercegovac, 2012; Juslin i Laukka, 2003, Krumhansl, 1997).

\section{Varijable $i$ instrument}

Osim osnovnih demografskih varijabli (dob, spol, škola), varijable vezane za ciljeve istraživanja uključivale su: 1) pristup u nastavi glazbene kulture, 2) procjenu spoznajnih elementa u glazbenim djelima te 
3) samoprocjenu doživljenih emocija potaknutih slušanjem umjetničke glazbe.

U nastavi su se primijenila dva pristupa: standardni (kontrolna grupa) i spoznajno-emocionalni (eksperimentalna grupa). Četiri instrumentalna umjetnička djela obrađena su u okviru oba pristupa. Za potrebe istraživanja standardni pristup pripremile su učiteljice/učitelji glazbene kulture, dok je prva autorica rada pripremila nastavu za spoznajno-emocionalni pristup. Različito dizajniran za svako glazbeno djelo, taj je pristup uključivao dodatne glazbene i neglazbene (povijesne, društvene, geografske, osobne...) elemente te multimedijalni, interaktivni i višemodalni pristup. Slušanje glazbe je, iako se uvijek ne tretira na takav način, višemodalno iskustvo kojemu je rezultat nešto što se može vidjeti, čuti i osjetiti (Ceraso, 2014). Isti autor napominje kako višemodalno slušanje omogućava učenicima i učenicama da budu prijemčivi slušatelji/slušateljice koji, na temelju različitih iskustava kojima su okruženi, slušaju i razumiju glazbu.

Tako su za Maskaradu učenice i učenici izrađivali maske, glumili i plesali na pripremljenu koreografiju. Uvodni dio skladbe realizirali su pjevanjem i izvođenjem ritamskog obrasca u trodobnoj mjeri (valcer). Prilikom obrade Maskarade naglasak je na slušnom prepoznavanju i određivanju glazbenog oblika djela koji se pojačava pokretima i glumom. Učenici i učenice su bili poticani na povezivanje priče, bazirane na tragediji koju je napisao M. J. Ljermontov, o ženi koja je otrovana uslijed nesporazuma, s osobnim iskustvima glede nesporazuma. $\mathrm{S}$ njima se razgovaralo i o životu skladatelja, povezujući ga sa stvarnim životom i njihovim iskustvima. U Wellingtonovoj pobjedi učenici i učenice su naučili pjevati pjesmu For He's a Jolly Good Fellow koju je Beethoven uveo u skladbu, a služila je za prepoznavanje i smještanje u kontekst sadržaja djela. Uvodni dio glazbenoga djela s izraženom ritamskom linijom bio je pogodan za sviranje učenica i učenika na pojedinim ritamskim instrumentima. Utvrđuju se sljedeći pojmovi: ritam, melodija, dinamika, crescendo, decrescendo, solo truba, tutti, visina tonova, a vrlo važan dio je utvrđivanje ugođaja i karaktera djela. Pri razgovoru i obradi Beethovenova života upućuje se na njegovu glazbenu dimenziju, ali i humane vrijednosti, kao strpljenje, hrabrost, upornost. Učenice i učenici bili su poticani na to da povežu značenje i posljedice rata i važnost mira. U Šeherezadi naglasak je bio na narativnim elementima, analizi likova, njihovim osobinama i vrijednostima. 
Kroz to djelo spoznali su: različiti karakter tema i notnih opisa, ugođaj, više i niže, duže i kraće tonove, uzlazno i silazno kretanje melodije; istovremeno kretanje melodije; usporedbu grafičkih slika i glazbenog teksta; određivanje glazbala. U pripravi za djelo Šeherezada, More i Sindbadov brod, od učenica i učenika se tijekom pripovijedanja tražilo da opišu lik i karakter Šeherezade i sultana na temelju njihovih dviju tema. Šeherezadu osim ljepote krase i hrabrost, mudrost i suosjećajnost, dok je u priči More i Sindbadov brod riječ o vrlo mudrom i vrlo bogatom trgovcu koji je uspio u životu uz veliki trud, na osnovu čega učenice i učenici izražavaju svoja stajališta i izvlače pouku. U Pavani glazba se slušala u različitim izvedbama uz video projekcije. Učenice i učenike poticalo se da razmišljaju o tome koga smatraju uzorom i koje stvari su im važne u životu. Uz svaku su skladbu slušali o skladatelju i njegovom životu i koje su njihove osobine osobito vrijedne. Ponavljaju se i utvrđuju sljedeće sastavnice: glazbala, ugođaj, karakter, ples, žanr. U pripravi za Pavanu naglasak je na multimediji jer se isto djelo sagledava u različitim formama, izvođačkim sastavima i žanrovima. Pitanja stručno-teorijskog i muzikološkog aspekta proširuju spoznajnu komponentu na emocionalnu tako da su učenici i učenice stavljeni u poziciju da razmišljaju, opisuju i vrednuju djelo, razlučuju o kvaliteti izvedbe i navode razloge.

Kratkim upitnikom ispitane su zamijećene glazbene sastavnice unutar devet spoznajnih elemenata. Spoznajni elementi odnose se na procjenu: tempa (je li skladba uglavnom brza), dinamike (je li skladba uglavnom tiha), ugođaja/karaktera (je li skladba: nježna, ${ }^{1}$ vedra, napeta, plesna), vrste glazbe (je li skladba instrumentalna), broja instrumenata (je li skladba pisana za jedan instrument), strukturalnog elementa (je li skladba pisana na način da se neki dijelovi ponavljaju). Zadatak učenika i učenica bio je odgovoriti očituje li se pojedina glazbena sastavnica u pojedinoj skladbi. Prema tome, ponuđeni su dihotomni odgovori (DA, NE). Prikupljeni odgovori učenika/učenica kodirani su s obzirom na točnost.

Kratkim upitnikom ispitano je u kojoj mjeri skladba pobuđuje svaku od sljedećih emocija: tugu, nadu, oduševljenje, strah, veselje,

${ }^{1}$ Opisi glazbe kao nježne, vedre ili napete uobičajeno se koriste za definiranje karaktera glazbe. Iako to jesu emocije, one se u spoznajnom segmentu slušanja glazbe odnose na to kako se glazba opisuje, a ne koje emocije pobuđuje, dok se u emocionalnom segmentu govori o tome koje emocije glazba pobuđuje. 
ljutnju, mržnju, gađenje, uznemirenost i iznenađenje. U upitniku je korišteno šest osnovnih emocija (veselje, tuga, ljutnja, strah, gađenje, iznenađenje) koje proizlaze iz psihologijskih teorija, te dodatne četiri specifičnije emocije (nada, oduševljenje, mržnja, uznemirenost) koje mogu biti povezane s glazbenim i izvanglazbenim sadržajem odabranih djela. Intenzitet doživljenih emocija procjenjivao se na skali od 5 stupnjeva, pri čemu 1 znači ne, 2 vrlo malo, 3 niti da, niti ne, 4 djelomično, a 5 da.

\section{Postupak}

Istraživanje je dio veće studije u kojoj se uspoređivao utjecaj standardnog i spoznajno-emocionalnog pristupa u nastavi glazbene kulture. Četiri djela odabrana su na temelju njihove melodijsko-ritamske i strukturalne građe, karakterne specifičnosti, primjerenosti dobi učenika i učenica, trajanja, kao i zbog pozadinske, glazbene i izvanglazbene konotacije.

Ove četiri skladbe, kao neovisne četiri nastavne jedinice, realizirane su u školama s razmakom od tri do četiri tjedna, a broj učenika i učenica varirao je od sata do sata, tako da je Maskaradu slušalo 557, Wellingtonovu pobjedu 435, Šeherezadu 498 i Pavanu 409 učenica i učenika. Svi učenici i učenice slušali su glazbena djela tri puta tijekom sata i anonimno ispunjavali upitnik koji je sadržavao pitanja o spoznajnom i emocionalnom aspektu slušanja glazbe nakon svakog slušanja. Tijekom uobičajene nastave glazbene kulture u trajanju od 45 minuta, 15 razreda radilo je po standardnom (kontrolna skupina), a 15 razreda po spoznajno-emocionalnom pristupu (eksperimentalna skupina), pri čemu su isti učitelji/učiteljice glazbe predavali na jedan i na drugi način.

\section{Rezultati}

\section{Spoznajni aspekt}

Da bi se ispitao utjecaj spoznajno-emocionalnog i standardnog pristupa u nastavi glazbe na spoznajni aspekt slušanja glazbe provjerena je točnost odgovora koje su dali učenici i učenice. Točni su odgovori prikazani u Tablici 1. 
Tablica 1. Točni odgovori vezani za spoznajne elemente skladbi

\begin{tabular}{|l|c|c|c|c|}
\hline \multicolumn{1}{|c|}{ Skladba je... } & Maskarada & $\begin{array}{c}\text { Wellingtonova } \\
\text { pobjeda }\end{array}$ & Šeherezada & Pavana \\
\hline brzog tempa & $\mathrm{Da}$ & $\mathrm{Da}$ & $\mathrm{Da}$ & $\mathrm{Ne}$ \\
\hline uglavnom tiha & $\mathrm{Ne}$ & $\mathrm{Ne}$ & $\mathrm{Ne}$ & $\mathrm{Da}$ \\
\hline nježna & $\mathrm{Ne}$ & $\mathrm{Ne}$ & $\mathrm{Da}$ i ne & $\mathrm{Da}$ \\
\hline vedra & $\mathrm{Da} \mathrm{i} \mathrm{ne}$ & $\mathrm{Ne}$ & $\mathrm{Da}$ i ne & $\mathrm{Da} \mathrm{i} \mathrm{ne}$ \\
\hline napeta & $\mathrm{Da}$ & $\mathrm{Da}$ & $\mathrm{Da}$ i ne & $\mathrm{Ne}$ \\
\hline plesna & $\mathrm{Da}$ & $\mathrm{Ne}$ & $\mathrm{Ne}$ & $\mathrm{Da}$ \\
\hline instrumentalna & $\mathrm{Da}$ & $\mathrm{Da}$ & $\mathrm{Da}$ & $\mathrm{Da} \mathrm{i} \mathrm{ne}$ \\
\hline $\begin{array}{l}\text { pisana za jedan } \\
\text { instrument }\end{array}$ & $\mathrm{Ne}$ & $\mathrm{Ne}$ & $\mathrm{Ne}$ & $\mathrm{Ne}$ \\
\hline dijelom ponavljajuća & $\mathrm{Da}$ & $\mathrm{Da}$ & $\mathrm{Ne}$ & $\mathrm{Da}$ \\
\hline
\end{tabular}

* U pojedinim elementima nekih skladbi oba su odgovora mogla biti točna

Napravljeni su hi-kvadrat testovi između odgovora učenika i učenica koji su imali standardni pristup i onih koji su imali spoznajno-emocionalni pristup za svaki element svake odslušane skladbe. Rezultati za svaku skladbu prikazani su u Tablici 2. 
Tablica 2. Točnost prepoznavanja spoznajnih elemenata prepoznatih slušanjem skladbi u dva pristupa nastavi

\begin{tabular}{|c|c|c|c|c|c|c|c|c|c|}
\hline \multirow{2}{*}{ Skladba je... } & \multirow{2}{*}{ 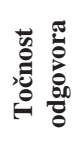 } & \multicolumn{2}{|c|}{ Maskarada } & \multicolumn{2}{|c|}{$\begin{array}{c}\text { Wellingtonova } \\
\text { pobjeda }\end{array}$} & \multicolumn{2}{|c|}{ Šeherezada } & \multicolumn{2}{|c|}{ Pavana } \\
\hline & & $\begin{array}{l}\text { Spoz.- } \\
\text { emoc. }\end{array}$ & Stand. & $\begin{array}{l}\text { Spoz.- } \\
\text { emoc. }\end{array}$ & Stand. & $\begin{array}{l}\text { Spoz.- } \\
\text { emoc. }\end{array}$ & Stand. & $\begin{array}{l}\text { Spoz.- } \\
\text { emoc. }\end{array}$ & Stand. \\
\hline \multirow{3}{*}{ brzog tempa } & $\mathrm{T}$ & 242 & 194 & 136 & 170 & 116 & 104 & 39 & 17 \\
\hline & $\mathrm{N}$ & 63 & 56 & 59 & 66 & 144 & 121 & 176 & 172 \\
\hline & & \multicolumn{2}{|c|}{$\chi^{2}=0.25$} & \multicolumn{2}{|c|}{$\chi^{2}=0.27$} & \multicolumn{2}{|c|}{$\chi^{2}=0.13$} & \multicolumn{2}{|c|}{$\chi^{2}=7.05^{* *}$} \\
\hline \multirow{3}{*}{ uglavnom tiha } & $\mathrm{T}$ & 27 & 22 & 17 & 22 & 101 & 65 & 149 & 147 \\
\hline & $\mathrm{N}$ & 274 & 228 & 177 & 213 & 162 & 158 & 66 & 42 \\
\hline & & \multicolumn{2}{|c|}{$\chi^{2}=0.01$} & \multicolumn{2}{|c|}{$\chi^{2}=0.05$} & \multicolumn{2}{|c|}{$\chi^{2}=4.60 *$} & \multicolumn{2}{|c|}{$\chi^{2}=3.69$} \\
\hline \multirow{3}{*}{ nježna } & $\mathrm{T}$ & 75 & 46 & 34 & 37 & 263 & 227 & 196 & 173 \\
\hline & $\mathrm{N}$ & 226 & 203 & 162 & 199 & 0 & 0 & 19 & 17 \\
\hline & & \multicolumn{2}{|c|}{$\chi^{2}=3.30$} & \multicolumn{2}{|c|}{$\chi^{2}=0.22$} & \multicolumn{2}{|c|}{ I } & \multicolumn{2}{|c|}{$\chi^{2}=0.01$} \\
\hline \multirow{3}{*}{ vedra } & $\mathrm{T}$ & 300 & 249 & 110 & 147 & 263 & 227 & 217 & 189 \\
\hline & $\mathrm{N}$ & 0 & 0 & 82 & 87 & 0 & 0 & 0 & 0 \\
\hline & & \multicolumn{2}{|c|}{ I } & \multicolumn{2}{|c|}{$\chi^{2}=1.35$} & \multicolumn{2}{|c|}{1} & \multicolumn{2}{|c|}{1} \\
\hline \multirow{3}{*}{ napeta } & $\mathrm{T}$ & 268 & 203 & 171 & 204 & 210 & 186 & 58 & 36 \\
\hline & $\mathrm{N}$ & 35 & 47 & 23 & 32 & 0 & 0 & 117 & 135 \\
\hline & & \multicolumn{2}{|c|}{$\chi^{2}=5.70^{* * *}$} & \multicolumn{2}{|c|}{$\chi^{2}=0.28$} & \multicolumn{2}{|c|}{ I } & $\chi^{2}=6$ & $.39 *$ \\
\hline pla & $\mathrm{T}$ & 146 & 140 & 79 & 99 & 152 & 96 & 171 & 142 \\
\hline plesna & $\mathrm{N}$ & 154 & 109 & 115 & 134 & 111 & 127 & 46 & 48 \\
\hline & & $\chi^{2}=$ & 3.12 & $\chi^{2}=$ & 0.14 & $\chi^{2}=10$ & $.50 * *$ & $\chi^{2}=$ & 0.94 \\
\hline instrumentaln & $\mathrm{T}$ & 278 & 233 & 176 & 228 & 248 & 198 & 216 & 188 \\
\hline instrumentaina & $\mathrm{N}$ & 23 & 14 & 18 & 8 & 13 & 22 & 0 & 0 \\
\hline & & $\chi^{2}=$ & 0.84 & $\chi^{2}=$ & $5.50 *$ & $\chi^{2}=4$ & $.46^{*}$ & 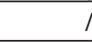 & \\
\hline pisana za je- & $\mathrm{T}$ & 16 & 13 & 14 & 13 & 24 & 15 & 17 & 22 \\
\hline dan instrument & $\mathrm{N}$ & 279 & 235 & 174 & 221 & 235 & 210 & 199 & 168 \\
\hline & & $\chi^{2}=$ & 0.01 & $\chi^{2}=$ & 0.62 & $\chi^{2}=$ & 1.10 & $\chi^{2}=$ & 1.60 \\
\hline dijelom & $\mathrm{T}$ & 281 & 237 & 171 & 215 & 184 & 151 & 165 & 154 \\
\hline ponavljajuća & $\mathrm{N}$ & 21 & 13 & 20 & 20 & 77 & 73 & 48 & 35 \\
\hline & & $\chi^{2}=$ & 0.73 & $\chi^{2}=$ & 0.48 & $\chi^{2}=$ & 0.54 & $\chi^{2}=$ & 0.99 \\
\hline
\end{tabular}

$\mathrm{df}=1$

$* \mathrm{p}<0.05$

$* * \mathrm{p}<0.01$

Rezultati (Tablica 2) pokazuju da se odgovori učenika i učenica ne razlikuju po točnosti ovisno o primjeni pristupa u nastavi slušanja glazbe, osim u Šeherezadi gdje učenice i učenici sa spoznajno-emocionalnim pristupom točnije ( $\mathrm{n}=152$ ili $58 \%$ ) procjenjuju skladbu plesnom u odnosu na kontrolnu grupu ( $\mathrm{n}=96$ ili 43 \%). U Maskaradi, Wellingtonovoj pobjedi i Šeherezadi više od polovice učenica i učenika točno 
je procijenilo pet, a u Pavani šest od devet elemenata slušane skladbe. Gledano prema elementima, u sve četiri skladbe više od polovice učenika i učenica točno je procijenilo da je skladba vedra, instrumentalna i ima li ponavljajuće dijelove. Najviše su griješili u procjeni je li djelo napisano za jedan instrument, je li plesno i je li tiho. U šest od sedam pronađenih značajnih razlika u procjenama elemenata, točne je odgovore dalo 5-15 \% više učenica i učenika koji su slušali po spoznajnoemocionalnom pristupu.

Premda je točnost odgovora uvelike slična neovisno o pristupu slušanju glazbe, nađeno je nekoliko razlika između grupe koja je slušala prema standardnom i grupe koja je slušala prema spoznajno-emocionalnom pristupu. Iako u obje skupine Maskaradu doživljavaju napetom, više učenica i učenika $(n=268$ ili $88 \%)$ doživljava je napetom u skupini sa spoznajno-emocionalnim nego u skupini sa standardnim pristupom $(\mathrm{n}=203$ ili $81 \%$ ). Iako u obje skupine Wellingtonovu pobjedu procjenjuju instrumentalnom, nešto manje ih je smatra takvom u skupini sa spoznajno-emocionalnim $(\mathrm{n}=176$ ili $91 \%)$ nego u skupini sa standardnim pristupom $(\mathrm{n}=228$ ili $97 \%)$. Šeherezadu u obje grupe doživljavaju tihom, no manje oni sa spoznajno-emocionalnim pristupom $(n=162$ ili $62 \%)$ u odnosu na standardni $(n=158$ ili $71 \%)$. I jedni i drugi je prepoznaju kao instrumentalnu, no nešto više oni sa spoznajno-emocionalnim pristupom $(\mathrm{n}=248$ ili $95 \%)$ u odnosu na one sa standardnim ( $\mathrm{n}=198$ ili $90 \%)$. Manje od polovice $(\mathrm{n}=111$ ili $42 \%)$ onih sa spoznajno-emocionalnim pristupom i više od polovice onih sa standardnim pristupom je doživljavaju plesnom $(\mathrm{n}=127$ ili $57 \%)$. Iako u obje skupine smatraju da je Pavana brzog tempa i napeta, nešto manje ih to smatra u skupini sa spoznajno-emocionalnim (brza: $\mathrm{n}=176$ ili 82 $\%$; napeta: $\mathrm{n}=117$ ili $67 \%$ ) nego u skupini sa standardnim pristupom (brza: $\mathrm{n}=172$ ili $91 \%$; napeta: $\mathrm{n}=135$ ili $79 \%$ ).

\section{Emocionalni aspekt}

Učenici i učenice su procjenjivali u kojoj mjeri svaka od skladbi u njima izaziva deset emocija. Da bi se ispitao utjecaj spoznajno-emocionalnog i standardnog pristupa u nastavi glazbe na emocionalni aspekt slušanja glazbe, zbog asimetričnih distribucija većine varijabli, napravljeni su Mann-Whitneyevi $U$ testovi za nezavisne uzorke. Napravljena je provjera za pojedinačne emocije unutar svake skladbe. Deskriptivni podaci i rezultati testova prikazani su u Tablici 3. 


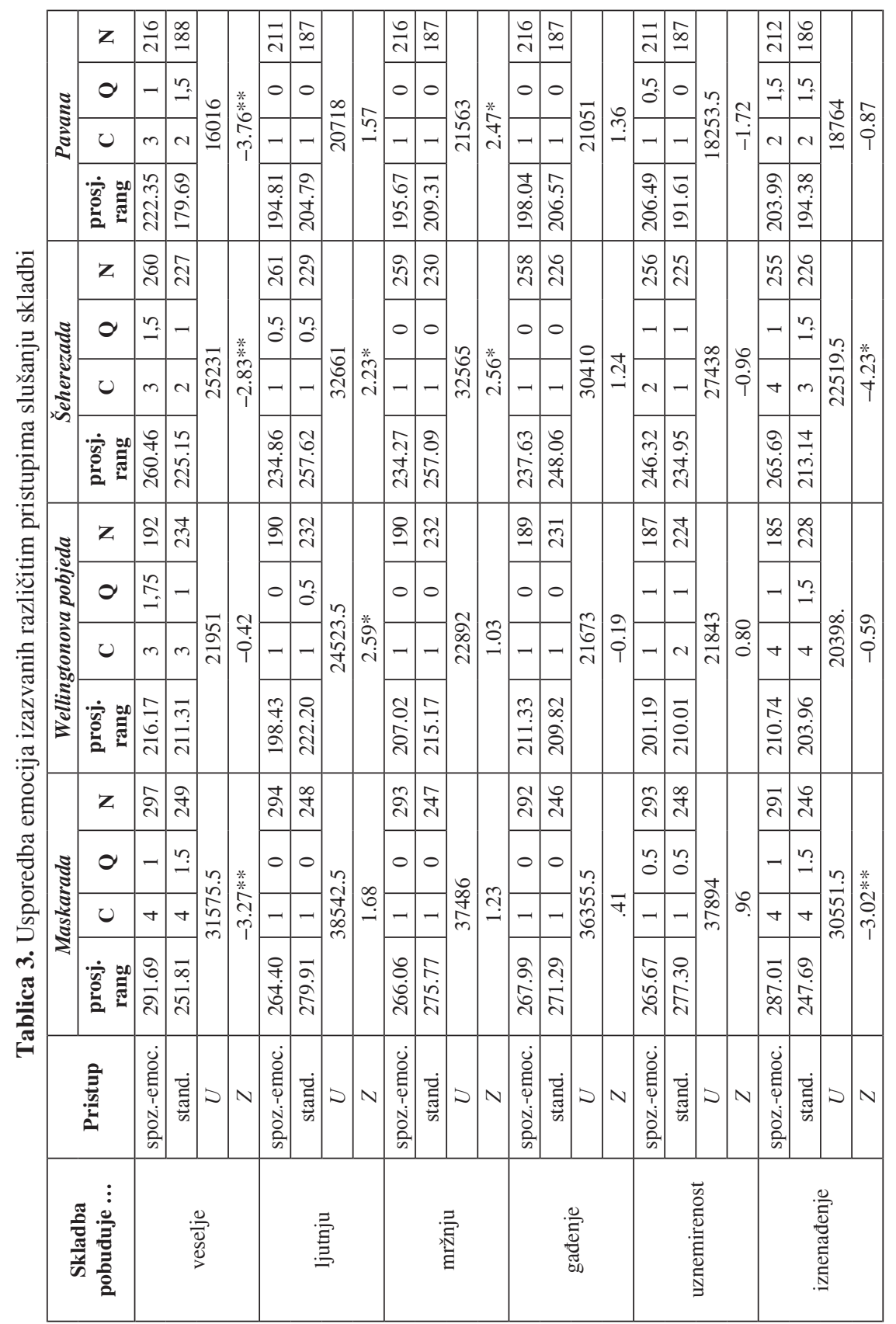




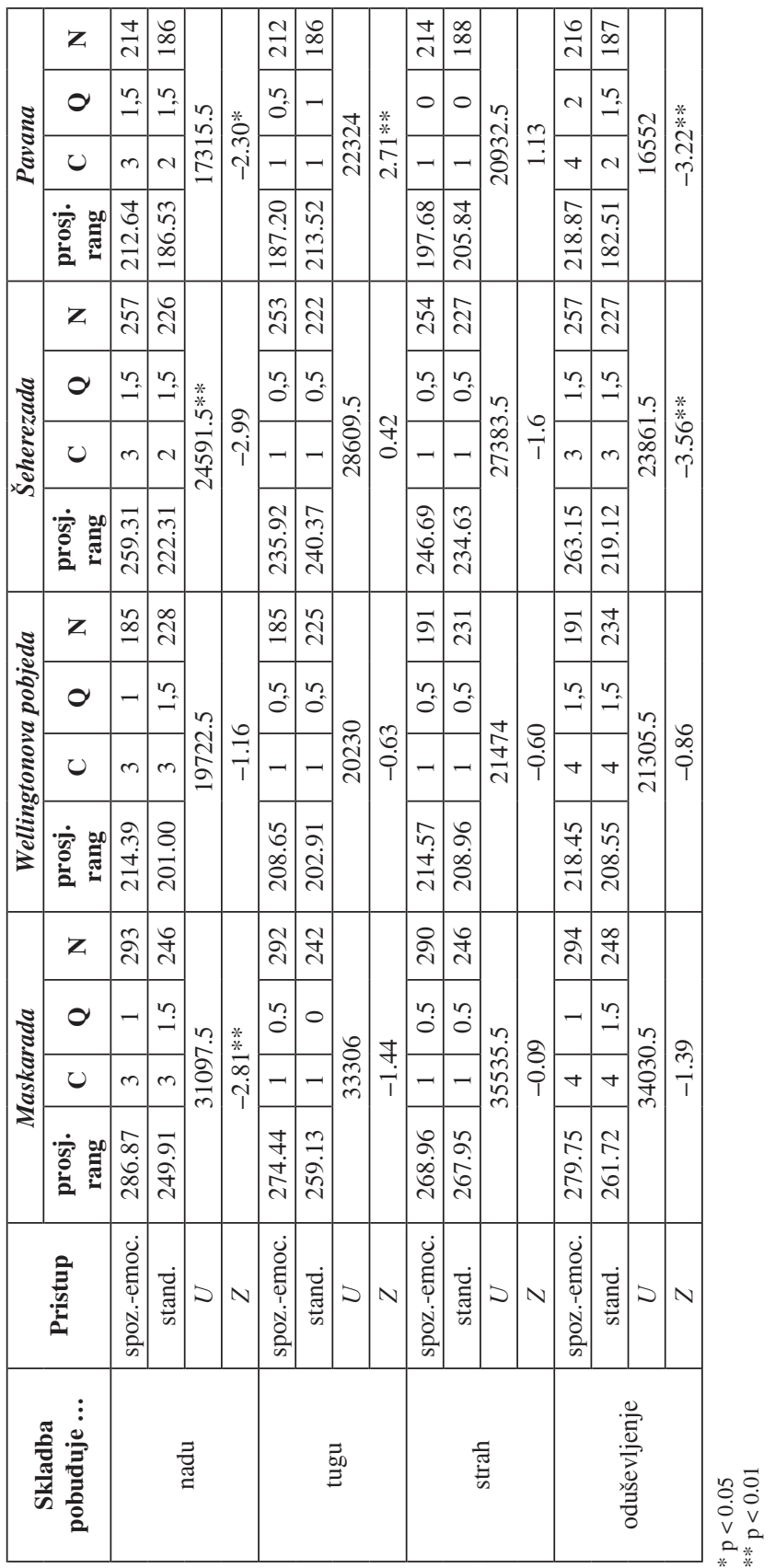


Općenito, iz Tablice 3 vidljivo je da Maskarada izaziva veselje, iznenađenje, nadu i oduševljenje, Wellingtonova pobjeda pobuđuje najviše iznenađenje i oduševljenje, dok Šeherezada i Pavana slabo potiču emocionalni odgovor.

Nadalje, rezultati pokazuju da je slušanje Maskarade kod učenica i učenika koji su je slušali prema spoznajno-emocionalnom pristupu potaknulo nešto više veselja, iznenađenja i nade nego kod učenika i učenica koji su je slušali na standardni način. Slušanje Wellingtonove pobjede pobudilo je manje ljutnje kod učenica i učenika koji su je slušali prema spoznajno-emocionalnom pristupu nego kod onih koji su je slušali prema standardnom. Slušanje Šeherezade kod učenica i učenika koji su imali nastavu prema spoznajno-emocionalnom pristupu nešto je više pobudilo veselje, iznenađenje, nadu i oduševljenje te manje ljutnju i mržnju nego kod učenika i učenica koji su imali nastavu prema standardnom pristupu. Sličan je nalaz dobiven i za Pavanu - nešto više veselja, nade i oduševljenja te manje mržnje i tuge osjećali su učenice i učenici koji su imali nastavu po spoznajno-emocionalnom pristupu. Općenito, potrebno je primijetiti da visine procjena dobivene u ovom istraživanju upućuju na tek primjetnu ili umjerenu manifestaciju emocionalnog doživljavanja.

\section{Rasprava}

\section{Spoznajni aspekt}

Odgovori učenica i učenika izloženih različitim metodičkim pristupima uglavnom se ne razlikuju u spoznajnom aspektu (Tablica 2), odnosno u davanju točnih procjena elementa skladbe koju su slušali i to se odnosi na sve četiri skladbe. Ovaj nalaz potvrđuje prvu hipotezu. Naime, od prvog razreda osnovne škole slušanje glazbe orijentirano je na to da se prepoznaje: naziv djela i skladatelja, tempo, dinamika, ugođaj, instrumenti, glasovi, oblici, vrste itd. Za svaki razred propisano je nastavnim programom koje sastavnice djeca trebaju prepoznati i razumjeti. Tako su do petog razreda svi učenici i učenice već u više navrata odgovarali na pitanja o brzini i jačini izvođenja glazbenog djela, određivali karakter/ugođaj, je li djelo vokalno ili instrumentalno te prepoznavali ponavlja li se neki dio u skladbi. U ovom istraživanju, najviše su griješili u procjeni je li djelo napisano za jedan instrument, je li plesno i tiho. Glede instrumenta, moguće da su doživjeli da jedan 
instrument dominira, a je li glazba plesna i tiha podložno je subjektivnoj procjeni. Naime nekome melodija može biti plesna iako skladba nije skladana kao plesna, dok doživljaj glasnoće može varirati jer jačina skladbe varira u skladbi.

Nekoliko je razlika ipak utvrđeno između kontrolne i eksperimentalne skupine. Učenice i učenici koji su bili izloženi spoznajno-emocionalnom pristupu Maskaradu su procijenili malo više napetom, čemu je vjerojatno pridonijelo uvođenje učenika i učenica u glazbeno djelo i priču, u kojem su saznali da se dogodilo ubojstvo. Eksperimentalna grupa Wellingtonovu pobjedu procijenila je malo manje instrumentalnom, moguce stoga što su tijekom sata pjevali For He's a Jolly Good Fellow i zbog specijalnih efekata kojima se dočarala borba. Šeherezadu su ocijenili kao manje tihu i plesnu te malo više instrumentalnu, što je opet vjerojatno posljedica uvodne priče u kojoj je naglasak na domišljatosti, asertivnosti i lukavosti glavne junakinje te na snazi i okrutnosti sultana. Za Pavanu su procijenili da ima manje brzi tempo i da je manje napeta. To je moguće pripisati interpretacijama različitih izvođača i izvođačica koje su slušali na satu i tako stekli ponešto različiti dojam od učenica i učenika u kontrolnoj skupini.

\section{Emocionalni aspekt}

Odabrane skladbe izazivaju uglavnom emocije ugodnog hedonističkog tona kod učenica i učenika (Maskarada i Wellingtonova pobjeda) ili slabo pobuđuju emocije (Šeherezada i Pavana), neovisno o metodičkom pristupu slušanja glazbe. Općenito umjerena manifestacija navedenih emocija očekivana je kada se slušanje glazbe odvija unutar razreda. Emocionalni doživljaj pod utjecajem je karakteristika glazbenog djela, onoga tko sluša te konteksta unutar kojega se slušanje glazbe odvija (Cespedes-Guevara i Eerola, 2018; Juslin, 2013). Slušanje glazbe u razredu grupna je aktivnost iako svaki slušatelj i slušateljica individualno pristupa tom zadatku zbog čega je vjerojatno da se učenice i učenici ne prepuštaju slušanju glazbe u potpunosti kao što to, moguće je, čine kad su je u prilici slušati na koncertu ili samostalno. Također, u razredu su tijekom slušanja glazbe svjesni da je ta aktivnost povezana s drugim aktivnostima na koje moraju također usmjeriti pažnju (usredotočiti se na različite aspekte glazbenog djela, razmišljati o zadacima koje će izvršavati nakon slušanja glazbe i slično). 
Dva su pristupa slušanju glazbe u ovome istraživanju pokazala da neke emocije mogu biti potaknute različito intenzivno (Tablica 3). Slušanje tri skladbe - Maskarade, Šeherezade i Pavane prema spoznajnoemocionalnom pristupu potaknulo je nešto viši stupanj emocionalnog doživljaja ugodnog hedonističkog tona nego standardno slušanje: više veselja i nade kod svake od njih, odnosno više iznenađenja u Maskaradi i Šeherezadi te više oduševljenja u Šeherezadi i Pavani. Emocije ovakvog tipa inače se i potvrđuju kao lakše za prepoznavanje i doživljavanje (Kallinen, 2005; Vieillard et al., 2008; Mohn, Argstatter i Wilker, 2011). Istodobno s intenzivnijim doživljavanjem ugodnih emocija, u tri su skladbe neke emocije neugodnog hedonističkog tona, koje su ionako bile slabo zastupljene, bile još slabije potaknute kad su učenice i učenici slušali skladbe prema spoznajno-emocionalnom pristupu. Tako je manje ljutnje bilo pobuđeno slušanjem Wellingtonove pobjede i Šeherezade, manje mržnje kod Šeherezade i Pavane te manje tuge slušanjem Pavane. Općenito, potrebno je istaknuti da su dobivene razlike među skupinama male što ne iznenađuje s obzirom na to da sama glazba i različite glazbene karakteristike prenose ili potiču javljanje emocija (Juslin i Laukka, 2003, Krumhansl, 1997). Ipak, objašnjenjem konteksta kroz uvodnu priču i druge neglazbene aktivnosti moguće je neke elemente koje glazba donosi naglasiti ili reducirati.

Ovakvi nalazi djelomično potvrđuju drugu hipotezu. Objašnjenje za različito intenzivno doživljavanje emocija različitog hedonističkog tona vjerojatno se može naći u dominantnim segmentima didaktičke artikulacije nastave gdje su učenici i učenice, uz brojne detektirane glazbene detalje u svakom pojedinom djelu, dobili uvid u cjelokupnu muzikološku dimenziju djela uz različite aktivnosti i višemodalni pristup.

\section{Zaključak}

Rezultati idu u prilog uporabe spoznajno-emocionalnog pristupa slušanju glazbe na nastavi glazbene kulture ako se želi pobuditi jači ili slabiji emocionalni doživljaj glazbenog djela kod djece školske dobi. U istraživanju je moguće prepoznati nekoliko ograničenja. Jedno od njih je redoslijed izloženosti glazbenim djelima. Zbog noviteta spoznajnoemocionalnog pristupa, moguće je da je na doživljaj neke skladbe zbog njezinog reda slušanja to imalo utjecaj. Ograničenje se odnosi i na korišteni instrumentarij. Budući da su kreirani za potrebe ovog istraživanja, 
upitnici su ujedno u procesu provjere i nakon cjelokupnog istraživanja bit će jasnije koje su njihove prednosti i nedostaci. Preporuke za buduća istraživanja idu u smjeru biranja skladbi koje bi pobuđivale emocije iz raznolikijeg spektra, npr. koje bi izazivale tugu, strah, kako bi se vidjelo je li spoznajno-emocionalni pristup podjednako učinkovit i u tom dijelu spektra, vodeći pritom računa o tome da se takve emocije smjeste u prikladan kontekst te da se nastavni sat završi u neutralnom ozračju. Uz skladbe apsolutnog, u dalje istraživanje mogu se uključiti i skladbe programnog karaktera koji utječe na glazbeni doživljaj. Iako izvanglazbene asocijacije mogu pomoći u razumijevanju i prihvaćanju glazbenoga djela, Antović, Stamenković i Figar (2016) napominju kako izvanglazbene asocijacije na naslov djela programne glazbe koje dodjeljuje skladatelj/ skladateljica nisu uvijek podložne istoznačnoj interpretaciji značenja koje je djelu pridano. Također, dobro bi bilo različiti glazbeni materijal didaktički pripremiti na iste načine kako bi se moglo provjeriti koji je didaktički pristup najučinkovitiji za koju glazbu u postizanju boljih rezultata u spoznajnom aspektu slušanja glazbe, u poticanju emocija itd. Osim toga, bilo bi korisno primijeniti spoznajno-emocionalni pristup s ciljem razlikovanja emocija kojima je glazba obojana i emocija koje glazba kod učenica i učenika pobuđuje. Spoznajno-emocionalni pristup $\mathrm{u}$ ovome je dijelu istraživanja pokazao prednost u odnosu na standardni pristup slušanju glazbe svojim višekontekstualnim pristupom, glazbenim i izvanglazbenim aktivnostima, povećanom interakcijom te aktivnim sudjelovanjem učenika i učenica na nastavi glazbene kulture.

\section{Literatura}

Antović, Mihailo, Stamenković, Dušan i Figar, Vladimir (2016), »Association of Meaning in Program Music: On denotation, inherence, and onomatopeia«, Music Perception, 34(2), str. 243-248. doi: https://doi.org/10.1525/mp.2016.34.2.243

Baumgartner, Hans (1992), »Remembrance of things past: Music, autobiographical memory, and emotion«, Advances in Consumer Research, 19, str. 613-620.

Ceraso, Steph (2014), »(Re)educating the senses: Multimodal listening, bodily learning, and the composition of sonic experiences«, College English, 77(2), str. 102-123.

Cespedes-Guevara, Julian i Eerola, Tuomas (2018), »Music communicates affects, not basic emotions - a constructionist account of attribution of emotional meanings to music «, Frontiers in psychology, 9, str. 215. doi: https://doi.org/10.3389/fpsyg.2018.00215 
Clarke, Eric F. (2005), Ways of Listening: An Ecological Approach to the Perception of Musical Meaning, Oxford: Oxford University Press.

Corrigall, Kathleen A. i Shellenberg, E. Glenn (2013), »Music: The Language of Emotion«, u: Mohiyeddini, Changiz; Eysenck, Michael i Bauer, Stephanie (ur.), Handbook of Psychology of Emotions, New York: Nova Science Publishers, str. 299-325.

Dalla Bella, Simone; Peretz, Isabelle; Rousseau, Luc i Gosselin, Nathalie (2001), »A developmental study of the affective value of tempo and mode in music «, Cognition, 80, B1-B10. doi: https://doi.org/10.1016/S0010-0277(00)00136-0

DeNora, Tia (2003), After Adorno, Cambridge: Cambridge University Press. doi: https://doi.org/10.1017/CBO9780511489426

Dobrota, Snježana i Reić Ercegovac, Ina (2012), »Odnos emocionalne kompetentnosti i prepoznavanja emocija u glazbi«, Društvena istraživanja, 21(4), str. 969-988. doi: https://doi.org/10.5559/di.21.4.08

Duraković, Lada (2016), »Glazbena nastava i ideologijske mijene: Hrvatska u formativnim godinama socijalizma (1945.-1960.) i razdoblju afirmacije političkoga pluralizma (1991.-2006.)«, u: Balić, Vito i Radica, Davorka (ur.), Glazbena pedagogija u svjetlu sadašnjih i budućih promjena 4, Split: Umjetnička akademija u Splitu, str. 395-413.

Eerola, Tuomas (2011), »Are the emotions expressed in music genre-specific? An audio-based evaluation of datasets spanning classical, film, pop and mixed genres «, Journal of New Music Research, 40(4), str. 349-366. doi: https://doi.org/10.1080/09298215.2011.602195

Gabrielsson, Alf i Juslin, Patrik N. (2003), »Emotional expression in music«, u: Davidson, Richard J.; Scherer, Klaus R. i Goldsmith, H. Hill (ur.), Handbook of affective sciences, Oxford: Oxford University Press, str. 503-534.

Hunter, Patrick G.; Schellenberg, E. Glenn i Schimmack, Ulrich (2010), »Feelings and perceptions of happiness and sadness induced by music: Similarities, differences, and mixed emotions «, Psychology of Aesthetics, Creativity, and the Arts, 4(1), str. 47-56. doi: https://doi.org/10.1037/a0016873

Hunter, Patrick G.; Schellenberg, E. Glenn i Stalinski, Stephanie M. (2011), »Liking and identifying emotionally expressive music: Age and gender differences«, Journal of Experimental Child Psychology, 110(1), str. 80-93.

doi: https://doi.org/10.1016/j.jecp.2011.04.001

Juslin, Patrik N. (2000), »Vocal expression and musical expression: Parallels and contrasts «, u: Kappas, Arvid (ur.), Proceedings of the Sixteenth Conference of the International Society for Research on Emotions, Quebec City: ISRE Publications, str. 281-284.

Juslin, Patrik N. (2013), »From everyday emotions to aesthetic emotions: Toward a unified theory of musical emotions «, Physics of Life Reviews, 10(3), str. 235-266. doi: https://doi.org/10.1016/j.plrev.2013.05.008 
Juslin, Patrik N.; Barradas, Gonçalo i Eerola, Tuomas (2015), »From sound to significance: Exploring the mechanisms underlying emotional reactions to music«, The American journal of Psychology, 128(3), str. 281-304.

doi: https://doi.org/10.5406/amerjpsyc.128.3.0281

Juslin, Patrik N. i Laukka, Petri (2003), »Communication of emotions in vocal expression and music performance: Different channels, same code?«, Psychological Bulletin, 129(5), str. 770-814.

doi: https://doi.org/10.1037/0033-2909.129.5.770

Juslin, Patrik N. i Laukka, Petri (2004), »Expression, perception, and induction of musical emotions: A review and a questionnaire study of everyday listening «, Journal of New Music Research, 33(3), str. 217-238.

doi: https://doi.org/10.1080/0929821042000317813

Juslin, Patrik N.; Liljeström, Simon; Laukka, Petri; Västfjäll, Daniel i Lundqvist, Lars-Olov (2011), »Emotional reactions to music in a nationally representative sample of Swedish adults: Prevalence and causal influences «, Musicae Scientiae, 15(2), str. 174-207. doi: https://doi.org/10.1177/1029864911401169

Juslin, Patrik N.; Liljeström, Simon; Västfjäll, Daniel i Lundqvist, Lars-Olov (2010), »How does music evoke emotions? Exploring the underlying mechanisms«, u: Juslin, Patrik N. i Sloboda, John A. (ur.), Handbook of Music and Emotion: Theory, research, applications, Oxford: Oxford University Press, str. 605-642. doi: https://doi.org/10.1093/acprof:oso/9780199230143.003.0022

Juslin, Patrik N.; Liljeström, Simon; Västfjäll, Daniel; Barradas, Gonçalo i Silva, Ana (2008), »An experience sampling study of emotional reactions to music: Listener, music, and situation«, Emotion, 8(5), str. 668-683.

doi: https://doi.org/10.1037/a0013505

Juslin, Patrik N. i Västfjäll, Daniel (2008), »Emotional responses to music: The need to consider underlying mechanisms «, Behavioral and Brain Sciences, 31(5), str. 559-575. doi: https://doi.org/10.1017/S0140525X08005293

Kallinen, Kari (2005), »Emotional ratings of music excerpts in the Western art music repertoire and their self-organization in the Kohonen Neural Network «, Psychology of Music, 33(4), str. 373-393.

doi: https://doi.org/10.1177/0305735605056147

Kratus, John (1993), »A developmental study of children's interpretation of emotion in music «, Psychology of Music, 21(1), str. 3-19.

doi: https://doi.org/10.1177/030573569302100101

Krumhansl, Carol L. (1997). »An exploratory study of musical emotions and psychophysiology«, Canadian Journal of Experimental Psychology, 51(4), 336-353. doi: https://doi.org/10.1037/1196-1961.51.4.336 
Milanković, Vera (2018), »Poimanje muzike«, u: Petrović, Milena (ur.), Muzički identiteti, Beograd: Fakultet muzičke umetnosti, str. 9-20.

Mohn, Christine; Argstatter, Heike i Wilker, Friedrich-Wilhelm (2011), »Perception of six basic emotions in music «, Psychology of Music, 39(4), str. 503517. doi: https://doi.org/10.1177/0305735610378183

Nastavni plan i program (2006), Zagreb: Ministarstvo znanosti, obrazovanja i sporta.

Perlovsky, Leonid (2008), »Music and consciousness«, Physics of Life Reviews, 7, str. 2-27. doi: https://doi.org/10.1016/j.plrev.2009.11.001

Požgaj, Joža (1988), Metodika nastave glazbene kulture u osnovnoj školi, Zagreb: Školska knjiga.

Rojko, Pavel (1996), Metodika nastave glazbe. Teorijsko-tematski aspekti, Osijek: Sveučilište Josipa Jurja Strossmayera, Pedagoški fakultet.

Russell, James A. (2003), »Core affect and the psychological construction of emotion «, Psychological Review, 110(1), str. 145-172. doi: https://doi.org/10.1037/0033-295X.110.1.145

Sloboda, John A. (1991), »Music structure and emotional response: Some empirical findings «, Psychology of Music, 19(2), str. 110-120. doi: https://doi.org/10.1177/0305735691192002

Sokolov, Evgeniy N. (1963), »Higher nervous functions: The orienting reflex«, Annual Review of Physiology, 25(1), str. 545-580.

doi: https://doi.org/10.1146/annurev.ph.25.030163.002553

Spasojević-Stojanović, Gordana (2013), »Savremeni pristup sadržajima slušanja instrumentalne muzike u mlađim razredima osnovne škole«, Nova škola, 8(2), str. 135-155. doi: http://dx.doi.org/10.7251/NSK1312010S

Vidulin, Sabina i Plavšić, Marlena (2020), »Student' reflections and motivation in the context of the cognitive-emotional approach to music listening «, u: Svalina, Vesna (ur.), Glazbena pedagogija u svjetlu sadašnjih i budućih promjena 7, Osijek: Fakultet za odgojne i obrazovne znanosti (prihvaćeno za objavljivanje).

Vidulin, Sabina i Radica, Davorka (2017), »Spoznajno-emocionalni pristup slušanju glazbe u školi: teorijsko polazište«, u: Vidulin, Sabina (ur.), Glazbena pedagogija u svjetlu sadašnjih i budućih promjena 5, Pula: Sveučilište Jurja Dobrile u Puli, str. 55-71.

Vieillard, Sandrine; Peretz, Isabelle; Gosselin, Nathalie; Khalfa, Stéphanie; Gagnon, Lise i Bouchard, Bernard (2008), »Happy, sad, scary and peaceful musical excerpts for research on emotions «, Cognition \& Emotion, 22(4), str. 720-752. doi: https://doi.org/10.1080/02699930701503567 


\title{
A COMPARISON BETWEEN THE COGNITIVE AND EMOTIONAL ASPECTS OF MUSIC LISTENING IN THE CONTEXT OF PRIMARY SCHOOL MUSIC TEACHING
}

\author{
Sabina Vidulin, Marlena Plavšić, Valnea Žauhar
}

The purpose of music listening in school is to shape students' world view regarding culture and arts, as well as to contribute to their aesthetic education. In Croatian compulsory education, the 'standard model' is used, which focuses on the cognitive dimension. In order to increase attention, motivation, listening habits, and acceptance of artistic music, a cognitive-emotional approach is suggested that connects musical and extra-musical content in multiple modalities. The aim of the study was to compare the effects of the cognitive-emotional approach versus the standard approach to music teaching on the cognitive and emotional aspects of music listening. 557 students from 30 fifth-grade classes participated in the research. They listened to Khachaturian's Masquerade, Beethoven's Wellington's Victory, Rimsky-Korsakov's Scheherazade, and Fauré's Pavane, as well as answered questions related to the cognitive and emotional aspects of music listening. Fifteen classes used the standard approach, while the other fifteen used the cognitive-emotional approach. Student responses generally did not differ in the cognitive aspect. In the emotional aspect, Scheherazade and Pavane engendered somewhat more intense dominant emotions when the cognitive-emotional approach was used.

Key words: music listening, musical pieces, teaching musical culture, standard approach, cognitive-emotional approach 